Journal of Economic and Social Measurement 16 (1990) 255

IOS Press

\title{
CONTENTS OF VOLUME 16
}

R.J. PAUL, Workers' Compensation - An Adequate Employee Benefit Now?

R.H. McGUCKIN, S.V. NGUYEN, Public Use Microdata: Disclosure and Usefulness

S.E. HABER, Recipient Value and Market Value: How They Measure up in Counting the Poor

L. SCHEMBRI, E. BEAULIEU, The Construction of Capital Stock Estimates of the Establishment Level: A Canadian Example

M. NICHOLSON, K.G. WILLIS, The Scale and Distribution of Financial Subsidies to Owner-Occupier Households: A Comparison of Estimates Derived from Building Society Records with Those of the Joseph Rowntree Memorial Trust Random Sample Survey

S.E. LEVITAN, F. GALLO, Workforce Statistics: Do We Know What We Think We Know - And What We Should Know?

U. KOHLI, Growth Accounting in the Open Economy: Parametric and Non-Parametric Estimates

J.H. HERBERT, Multiple Comparison Procedures and the Analysis of Natural Gas Demand Behavior

D. BUCKMASTER, E. SANIGA, Distributional Forms of Financial Accounting Ratios: Pearson's and Johnson's Taxonomies

P.A. COOMES, D.O. OLSON, Using BEA and BLS Data to Monitor Metropolitan Area Economic Performance

M.T. DUGAN, K.A. SHRIVER, A.C. WILSON, The Utilization of the Census X-11 Model for Audit Planning Purposes

C.W. CHRISTIAN, Endogenous Sampling in the Statistics of Income Panel of Individual Returns

N. SICHERMAN, The Measurement of On-the-Job Training

K.J. HAYES, P.J. LAMBERT, G.W. SCULly, D.J. SLOTTJE, The Equality-Efficiency Trade-Off: An Approach to Measurement and some Estimates for the U.S. Economy

S.E. HABER, The Fungible Value of Government and Employed Provided InKind Health Benefits

Contributors to Articles for Volume 16 